\title{
Molecular interactions between the olive and the fruit fly Bactrocera oleae
}

\author{
Giandomenico Corrado ${ }^{1}$, Fiammetta Alagna ${ }^{2}$, Mariapina Rocco ${ }^{3}$, Giovanni Renzone ${ }^{4}$, Paola Varricchio ${ }^{1}$, \\ Valentina Coppola ${ }^{1}$, Mariangela Coppola ${ }^{1}$, Antonio Garonna ${ }^{5}$, Luciana Baldoni ${ }^{2}$, Andrea Scaloni ${ }^{4}$ and Rosa Rao ${ }^{1 *}$
}

\begin{abstract}
Background: The fruit fly Bactrocera oleae is the primary biotic stressor of cultivated olives, causing direct and indirect damages that significantly reduce both the yield and the quality of olive oil. To study the olive- $B$. oleae interaction, we conducted transcriptomic and proteomic investigations of the molecular response of the drupe. The identifications of genes and proteins involved in the fruit response were performed using a Suppression Subtractive Hybridisation technique and a combined bi-dimensional electrophoresis/nanoLC-ESI-LIT-MS/MS approach, respectively.

Results: We identified 196 ESTs and 26 protein spots as differentially expressed in olives with larval feeding tunnels. A bioinformatic analysis of the identified non-redundant EST and protein collection indicated that different molecular processes were affected, such as stress response, phytohormone signalling, transcriptional control and primary metabolism, and that a considerable proportion of the ESTs could not be classified. The altered expression of 20 transcripts was also analysed by real-time PCR, and the most striking differences were further confirmed in the fruit of a different olive variety. We also cloned the full-length coding sequences of two genes, Oe-chitinase I and Oe-PR27, and showed that these are wound-inducible genes and activated by B. oleae punctures.

Conclusions: This study represents the first report that reveals the molecular players and signalling pathways involved in the interaction between the olive fruit and its most damaging biotic stressor. Drupe response is complex, involving genes and proteins involved in photosynthesis as well as in the production of ROS, the activation of different stress response pathways and the production of compounds involved in direct defence against phytophagous larvae. Among the latter, trypsin inhibitors should play a major role in drupe resistance reaction.
\end{abstract}

Keywords: Olea europea, Pest, SSH, Proteomics, Defence, Fruit fly

\section{Background}

The olive fruit fly Bactrocera oleae (Rossi) (Diptera: Tephritidae) is the most harmful pest of olives worldwide [1]. Primarily known as a cause of significant yield loss in almost all of the countries of the Mediterranean Basin (where the major olive and oil producing countries are located), this monophagous pest is currently also present in new areas of cultivation, such as South Africa and North and Central America [2,3]. The olive fruit fly is able to reduce crop yield in several ways [1]. Adult

\footnotetext{
*Correspondence: rao@unina.it

'Dipartimento di Scienze del Suolo, Pianta, Ambiente e Produzioni Animali, Universita' degli Studi di Napoli Federico II, Via Università 100, Portici, Napoli 80055, Italy

Full list of author information is available at the end of the article
}

females injure drupes through their oviposition on the ripening fruits. The newly hatched larva will grow as a fruit borer, excavating a tunnel in the mesocarp until pupation. Larval feeding causes yield loss primarily by pulp consumption and inducing premature fruit dropping. Additionally, infested fruits present an alteration of their organoleptic features that makes them unsuitable for direct consumption, transformation or pressing [4]. Although the availability and quality of host fruits, along with climate, represent important triggers of $B$. oleae outbreaks, it has been estimated that the average crop loss is in the range of $5-30 \%$ of the total olive production, even with intense chemical control measures $[3,5]$. Conventional management methods rely on insecticide applications to control the fly after monitoring the adult 
population [1]. Unfortunately, similarly to many other pests, populations of $B$. oleae have acquired insensitivity to insecticides [6,7]. Moreover, classical biological control programs have not been successful, particularly in that they fail to consistently provide adequate levels of control across the range of climates and of cultivated olive varieties [1].

Despite the severe impact on yield, comprehensive studies on the olive response and on resistance mechanisms to the fruit fly are still lacking. Olive cultivars differ in the degree of susceptibility to fruit fly infestation [1], but the factors underlying this trait are still controversial $[8,9]$. A strong tolerance, defined mainly by assessing the severity of the infestation, has been reported in some cultivated varieties [1]. However, even the so-called "resistant" cultivars may suffer considerable attacks under intense infestation pressure [10]. It is likely that the differential susceptibility to the fruit fly may involve a number of morphological, physiological and phenological parameters, which include mechanical obstruction, fruit composition and the amount of chemicals involved in plant direct and indirect defence $[8,11,12]$. Unfortunately, studies aimed at the description of the molecular response of the olive to $B$. oleae are also much needed to understand the mechanisms and the players of olive defence, eventually improving stress resistance, increasing yield and facilitating the molecular selection of olive varieties more suitable for Integrated Pest Management.

To gain a more thorough understanding of the consequences of the olive-fruit fly interaction, we studied the molecular response of the fruits at the transcriptional and proteomic levels. Due to the limited information on the olive genome, a PCR approach on subtracted cDNA libraries was used. The PCR-based Suppression Subtractive Hybridisation ( $\mathrm{SSH}$ ) technique was developed for a sensitive comparison of mRNA expression patterns between two cDNA populations [13]. This methodology has been successfully exploited to analyse plant responses to biotic or abiotic stress and changes between different developmental stages or tissues [14-18]. Although the SSH method has been widely used in the animal, prokaryotic and human fields, it is particularly useful for species that lack genomic data [19]. In parallel, a bidimensional electrophoresis analysis of protein extracts was used to identify specific proteomic changes in drupes with larval feeding tunnels. Gel-based proteomic studies have been extensively used to investigate protein expression changes in plant tissues during responses to biotic or abiotic stress and to highlight molecular signatures in genotypes with higher levels of resistance to insects or fungi [20-24]. Our transcriptomic and proteomic analyses allowed us to reveal the molecular bases and related signalling pathways induced in the interaction between olive and its most damaging biotic pest.

\section{Results}

\section{Construction of the subtracted library and sequence analysis}

A subtracted library was constructed to identify olive genes whose expression is affected by $B$. oleae infestation. The cDNA library was obtained using RNA from fruits with larval feeding tunnels as tester and from undamaged fruits as driver. Blue/white selection and restriction digestion identified 590 recombinant colonies out of 1,180 . After filtering for size by restriction analysis (>200 bp), the recombinant plasmids were sequenced and the clones with low information content were removed. The average length of the 196 cloned olive sequences was $303 \mathrm{bp}$, from a minimum of $69 \mathrm{bp}$ to a maximum of $766 \mathrm{bp}$. To obtain unique sequences (unigenes), we performed an assembly using the CAP3 program, which identified 87 singletons and clustered the remaining 111 sequences in 33 contigs, made up of 2 to 22 overlapping ESTs. The resulting non-redundant unigene dataset, following an in silico automated translation, was compared against available databases to find similarities with known sequences. Only three clones matched already available olive sequences. Matches with e-values lower than $10 \mathrm{e}-03$ were used to assign a putative function to the transcripts. Overall, $39.2 \%$ of the unigenes putatively code for proteins with significant similarity to annotated proteins in other organisms; these unigenes were named based on the homology (Additional file 1). The remaining 73 unigenes (60.8\%) were considered to be functionally unidentified. Unigenes with a blastX e-value higher than $10 \mathrm{e}-3$ were then compared with nucleotide databases. Fifty-two sequences revealed a significant similarity (e-value lower than 10e-3). Specifically, 27 (respectively 2) ESTs were annotated, choosing as the search set the non-redundant nucleotide collection (respectively the Expressed Sequence Tags collection) at NCBI. A significant similarity for another 23 clones was found by analysing the olive transcribed sequences at the OLEA EST db. All of these sequences are listed in Additional file 2. The proportion of sequences that were not annotated may be explained by the relatively small average length of the $\mathrm{SSH}$ fragments, the presence of fragments including UTR regions, which typically correspond to lessconserved regions of genes, or both. These two features are likely to be introduced by the subtraction technique $[25,26]$, which favours the cloning of relatively short fragments with lower degrees of conservation. The average length of the non-described sequences significantly differed from that of the annotated entries ( $t$-test; $p<0.01)$. However, over $71 \%$ of the SSH clones whose putative translation product could not be annotated nevertheless showed similarity with other plant transcripts. Approximately half of these clones 
found a match exclusively in the Olea EST database, suggesting that the lack of a functional annotation relative to a set of inducible genes, is also due to the existence of sequences that are specific to the olive tree.

Gene Ontology analysis of the non-redundant unigene collection was performed using the Blast2GO software, considering the limited information available regarding the olive genome. The sequences were classified into two ontology categories, namely, "Biological process" and "Molecular function" (Figure 1). Interestingly, in the category "Biological process", the most frequent entry was "Response to stress", followed by "Catabolic process". The most frequent "Molecular function" was hydrolase activity [27]. Among the annotated sequences in the SSH library, we identified several ESTs whose homologues in other species are associated with plant responses to biotic stress, such as proteins of the hydrolase family and proteinase inhibitors.

\section{Expression analysis of ESTs involved in plant defence}

The B. oleae-inducible expression of a selection of unigenes was also investigated by quantitative real-time PCR (qRT-PCR), as a verification based on an independent experimental method and material [28]. To this end, we selected from the library 18 unigenes representative of different biological processes, such as abiotic and biotic defence response, signal transduction, phytohormone signalling and transcriptional regulation. Furthermore, we included in the analysis two transcripts putatively coding for unclassified proteins (Table 1). The qRT-PCR experiments were performed using RNAs isolated from infested and control drupes of the cultivar 'Moraiolo' harvested in a different year. The real-time RT-PCR data indicated that ESTs exhibiting significant similarities to Trypsin Protease Inhibitor II, Trypsin/chymotrypsin Inhibitor, Pathogenesis Related protein 27 (PRp27) and chitinase I were the most highly inducible sequences by larval feeding

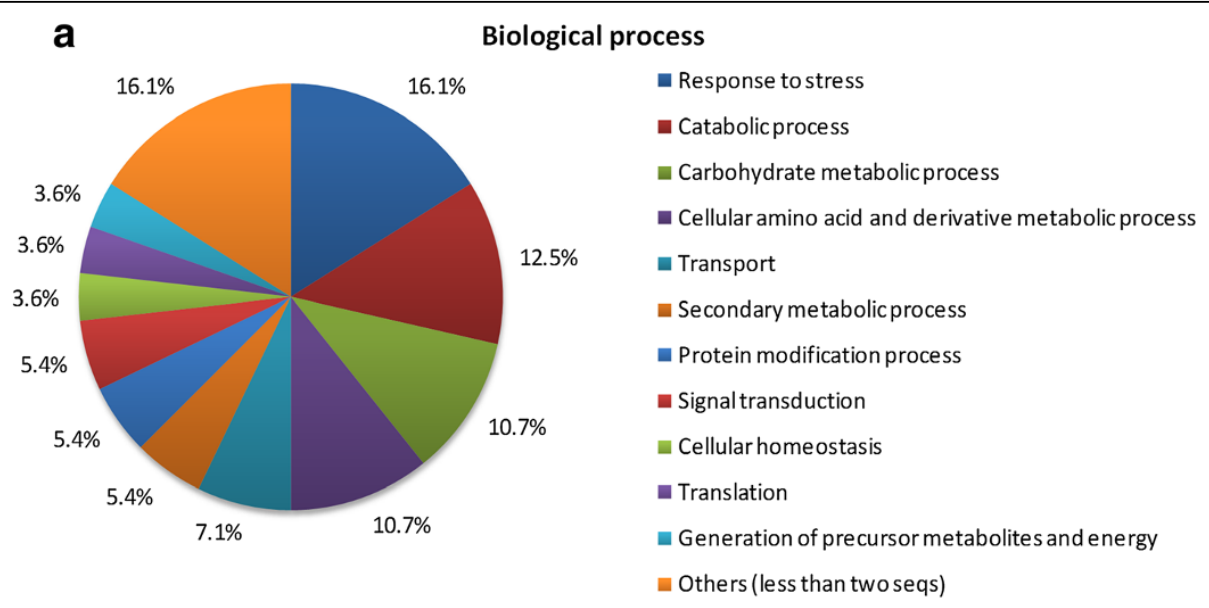

b

Molecular function

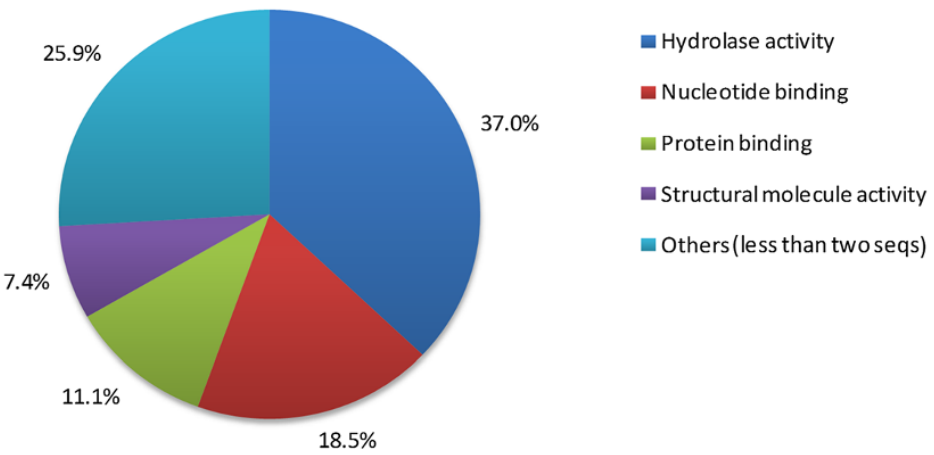

Figure 1 Distribution of biological process (a) and molecular function (b) terms of the 47 annotated unigenes following GO classification (73 sequences were not annotated). To provide a multi-level summary of the GO functions using a prepared plant $\mathrm{GO}$ set, we performed a Plant GoSlim annotation with a cut-off of two sequences. The category "others" includes DNA metabolic process, cell differentiation, response to biotic stimulus, response to abiotic stimulus, anatomical structure morphogenesis, cell death, flower development, growth, and response to endogenous stimulus for "biological process". For "molecular function" the category "others" includes kinase activity, receptor activity, carbohydrate binding, DNA binding, enzyme regulator activity, transporter activity, and transferase activity. 
Table 1 Genes selected for validation of expression by quantitative RT-PCR and their putative functions

\begin{tabular}{|c|c|c|c|c|c|}
\hline Gene name & ID & Acc. Number & Best similarity [Species]; acc. number & e-value & Gene Ontology terms \\
\hline \multirow[t]{2}{*}{ Aquaporin } & 148 & JQ711526 & Aquaporin PIP2 [Vitis vinifera]; ABN14353.1 & $3,60 \mathrm{E}-19$ & F: water channel activity \\
\hline & & & & & P: response to abscissic acid stimulus \\
\hline \multirow[t]{2}{*}{ Beta-glucosidase } & $\mathrm{C} 17$ & AAL93619.1 & Beta-glucosidase [Olea europaea]; AAL93619.1 & $1,08 \mathrm{E}-56$ & F:hydrolase activity \\
\hline & & & & & P:carbohydrate metabolic process \\
\hline \multirow[t]{2}{*}{ Catalase } & 119 & ABS72010.1 & Catalase [Olea europaea]; ABS72010.1 & $5.60 \mathrm{E}-23$ & F:catalase activity \\
\hline & & & & & P:response to oxidative stress \\
\hline \multirow[t]{2}{*}{ Chitinase } & 2 & JN696113 & $\begin{array}{l}\text { Extracellular chitinase, class I [Vitis vinifera]; } \\
\text { XP_002269972.1 }\end{array}$ & $7,55 \mathrm{E}-25$ & F: chitinase activity \\
\hline & & & & & P:defense response to fungus \\
\hline \multirow[t]{2}{*}{ Cinnamate 4 hydroxylase } & C32 & JQ711532 & $\begin{array}{l}\text { Trans-cinnamate 4-hydroxylase } \\
\text { [Populus tremuloides]; ABF69101.1 }\end{array}$ & $5,56 \mathrm{E}-39$ & $\begin{array}{l}\text { F: trans-cinnamate 4-monooxygenase } \\
\text { activity }\end{array}$ \\
\hline & & & & & P:response to wounding \\
\hline Disease resistance protein & C4 & JQ711509 & $\begin{array}{l}\text { Disease resistance response protein } 206 \\
\text { [Zea mays]; NP_001149569.1 }\end{array}$ & 9,94E-09 & P:defense response \\
\hline \multirow[t]{2}{*}{$\begin{array}{l}\text { Ethylene Responsive } \\
\text { Trascription Factor }\end{array}$} & $53 \mathrm{~F}$ & JK784503 & $\begin{array}{l}\text { Ethylene-responsive transcription factor (ERF) } \\
\text { [Olea europaea]; OLEEUCI001226:Contig3 }\end{array}$ & $1,00 \mathrm{E}-100$ & F: DNA binding \\
\hline & & & & & P: ethylene mediated signaling pathway \\
\hline \multirow[t]{2}{*}{ GST } & $59-P$ & JQ711516 & $\begin{array}{l}\text { Glutathione S-transferase } \\
\text { [Hyoscyamus muticus]; P46423.1 }\end{array}$ & 2.87E-21 & F: glutathione transferase activity \\
\hline & & & & & P: defense reponse \\
\hline \multirow[t]{2}{*}{ Lipoxygenase } & $301-P$ & EU513351 & $\begin{array}{l}\text { Lipoxygenase [Arabidopsis thaliana]; } \\
\text { CAC19365.1 }\end{array}$ & 7.00E-13 & F: lipoxygenase activity \\
\hline & & & & & P: response to wounding \\
\hline \multirow[t]{2}{*}{ Metallothionein type 1} & $52-\mathrm{L}$ & JQ711520 & $\begin{array}{l}\text { Metallothionein-like protein } \\
\text { [Pimpinella brachycarpa]; AAC62510.1 }\end{array}$ & $2,35 \mathrm{E}-10$ & F: copper ion binding \\
\hline & & & & & P: cellular copper ion homeostasis \\
\hline PRp27 & $\mathrm{C} 2$ & JN696114 & NtPRp27 [Nicotiana tabacum]; BAA81904.1 & 1,07E-78 & P:defense response \\
\hline \multirow[t]{2}{*}{ PR 10} & $\mathrm{C} 6$ & $J Q 711524$ & $\begin{array}{l}\text { Trypsin chymotrypsin inhibitor [Lens culinaris]; } \\
\text { CAR47883.1 }\end{array}$ & $1,10 \mathrm{E}-36$ & F: serine-type endopeptidase inhibitor \\
\hline & & & & & P: defense response \\
\hline \multirow[t]{2}{*}{$\begin{array}{l}\text { Serine-carboxypeptidase-like } \\
\text { protein }\end{array}$} & $C 29$ & JQ711528 & $\begin{array}{l}\text { Serine carboxypeptidase [Ricinus communis]; } \\
\text { EEF40335.1 }\end{array}$ & $1,22 \mathrm{E}-14$ & $\begin{array}{l}\text { F: serine-type carboxypeptidase } \\
\text { activity }\end{array}$ \\
\hline & & & & & P: proteolysis \\
\hline \multirow[t]{2}{*}{ Superoxide dismutase } & $3-\mathrm{F}$ & JK784468 & $\begin{array}{l}\text { Cu/Zn super-oxide dismutase (Ole e } 5 \text { allergen) } \\
\text { [Olea europaea]; AJ428575.2 }\end{array}$ & 2,09E-111 & F: superoxide dismutase activity \\
\hline & & & & & P: response to oxidative stress \\
\hline Transducin & $109-\mathrm{N}$ & JQ711533 & $\begin{array}{l}\text { Transducin family protein [Arabidopsis lyrata]; } \\
\text { EFH62484.1 }\end{array}$ & $4,52 \mathrm{E}-22$ & F:nucleotide binding \\
\hline \multirow[t]{2}{*}{ Trypsin Protease Inhibitor II } & $99-\mathrm{N}$ & JQ429796 & $\begin{array}{l}\text { Proteinase inhibitor type-2 } \\
\text { [Solanum lycopersicum]; CAA64416.1 }\end{array}$ & $1.14 \mathrm{E}-12$ & F: serine-type endopeptidase inhibitor \\
\hline & & & & & P: defense response \\
\hline \multirow[t]{2}{*}{$\begin{array}{l}\text { Trypsin/chymotrypsin } \\
\text { Inhibitor }\end{array}$} & 93 & JQ429797 & $\begin{array}{l}\text { Trypsin chymotrypsin inhibitor [Lens culinaris]; } \\
\text { CAR47883.1 }\end{array}$ & $1,10 \mathrm{E}-36$ & F: serine-type endopeptidase inhibitor \\
\hline & & & & & P: defense response \\
\hline \multirow[t]{2}{*}{$\begin{array}{l}\text { Ubiquitin-coniugating } \\
\text { enzyme }\end{array}$} & $\mathrm{C} 13$ & JQ429798 & $\begin{array}{l}\text { Ubiquitin-conjugating enzyme E2 } \\
\text { [Ricinus communis]; XP_002523377.1 }\end{array}$ & $7,64 \mathrm{E}-46$ & F: ubiquitin-protein ligase activity \\
\hline & & & & & P:response to iron ion \\
\hline Unknown protein 1 & $51-\mathrm{F}$ & JQ711535 & & & \\
\hline Unknown protein 2 & $\mathrm{C} 12$ & JQ711536 & & & \\
\hline
\end{tabular}




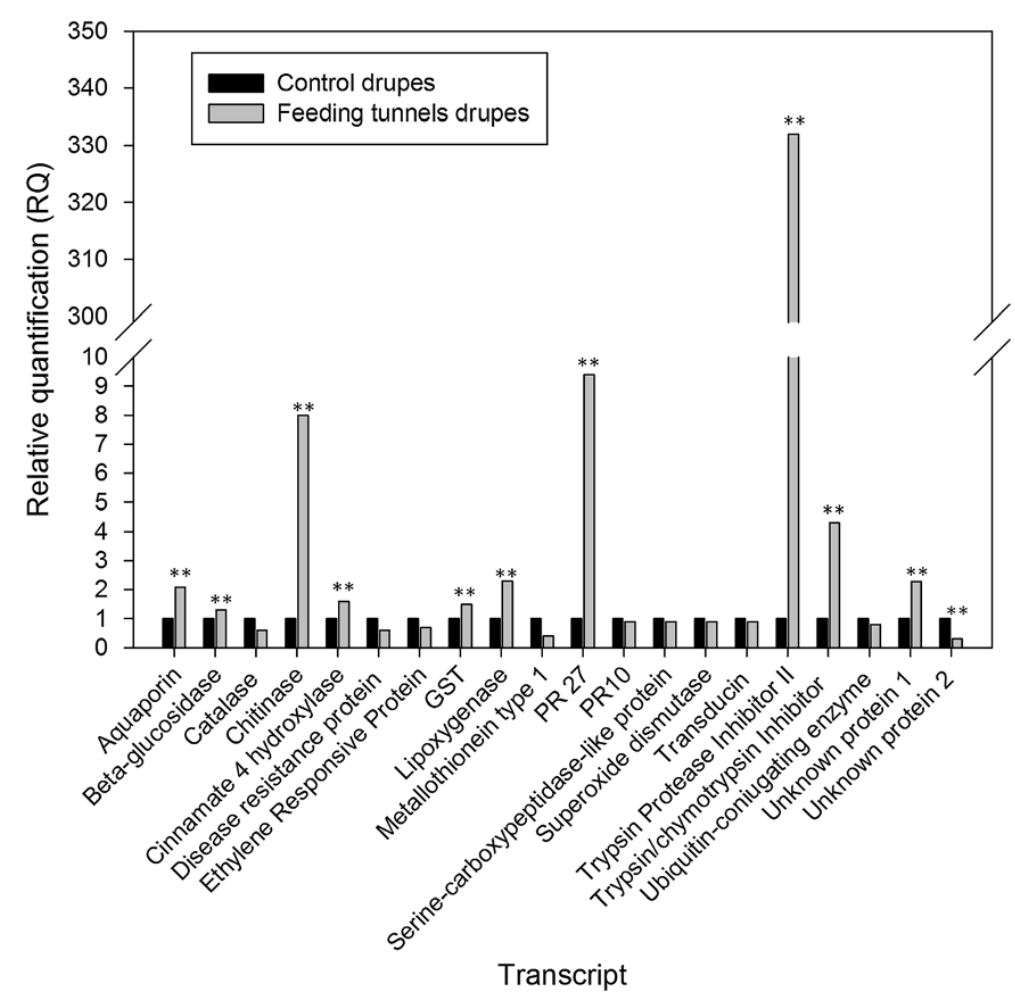

Figure 2 Real-time PCR analysis of the expression levels of transcripts putatively involved in defence against larval feeding. The genes are listed in Table 1. RNA was isolated from drupes of the cultivar 'Moraiolo'. The graph displays the relative quantity (RQ) for each target gene in the control (black bars) and infested drupes (grey bars), shown on a linear scale relative to the calibrator (control drupes). Asterisks indicate significant difference compared to control $(p<0.01)$.

(Figure 2). The high inducibility of TPI II was also confirmed in drupes of a different cultivar, 'Leccino' (Additional file 3).

\section{Identification of two full-length coding sequences and stress-response transcriptional analysis}

As part of this study, we identified the full-length coding sequences of two genes highly inducible by larval feeding and further characterised their involvement in plantinsect interactions. The cDNA fragments of PRp27 and chitinase were used as starting point for $5^{\prime}$ and $3^{\prime}$ RACE-PCRs. The assembly of the rescued cDNA fragments allowed us to identify the full-length coding sequences of 792 and $687 \mathrm{bp}$ for the olive chitinase and PR27 genes, respectively. Moreover, the 3' UTR and part of the $5^{\prime}$ UTR were also cloned. These genes were named Oe-Chitinase I (Acc. Num. JN696113) and OePRp27 (Acc. Num. JN696114).

The assembled cDNA sequence of Oe-Chitinase I was 947 bp with an ORF coding for a polypeptide containing 264 amino acids with a theoretical pI of 5.61 (Figure 3). This protein product has the highest sequence identity (81\%) with chitinase 1b of Vitis vinifera (Acc. Num. CAC14015) and contains a conserved domain typical of the Chitinase 19 superfamily. The lack of an N-terminal chitin-binding domain (a 30- to 43-residue motif organised around a conserved four-disulphide core) implies that Oe-Chi I belongs to the class IB/II. Proteins belonging to the Chitinase 19 family are enzymes whose function in plants is primarily associated with the defence response to fungal and insect pathogens. Bioinformatics revealed the presence of a 19 -amino acid $\mathrm{N}$-terminal Signal Peptide and the lack of a vacuole targeting signal, suggesting that Oe-Chi I is secreted into the extracellular space. Multiple alignment of the amino acid sequence to other plant chitinases revealed the presence of several conserved residues, most notably three catalytic residues, four sugar-binding sites and two signature patterns of the Chitinase 19 family (Figure 4).

The assembled cDNA sequence of Oe-PRp27 was 926 bp with an ORF coding for a polypeptide containing 229 amino acids (Figure 5). This protein product has the highest sequence identity (77\%) with NtPRp27 from $\mathrm{Ni}$ cotiana tabacum (Acc. Num. BAA81904). The predicted Oe-PRp27 protein contains a basic secretory protein (BSP) domain, which is believed to be typical of proteins involved in plant defence mechanisms against pathogens. Bioinformatic analysis indicated the presence of a 24amino acid N-terminal Signal Peptide. Multiple sequence alignment revealed the presence of five regions 


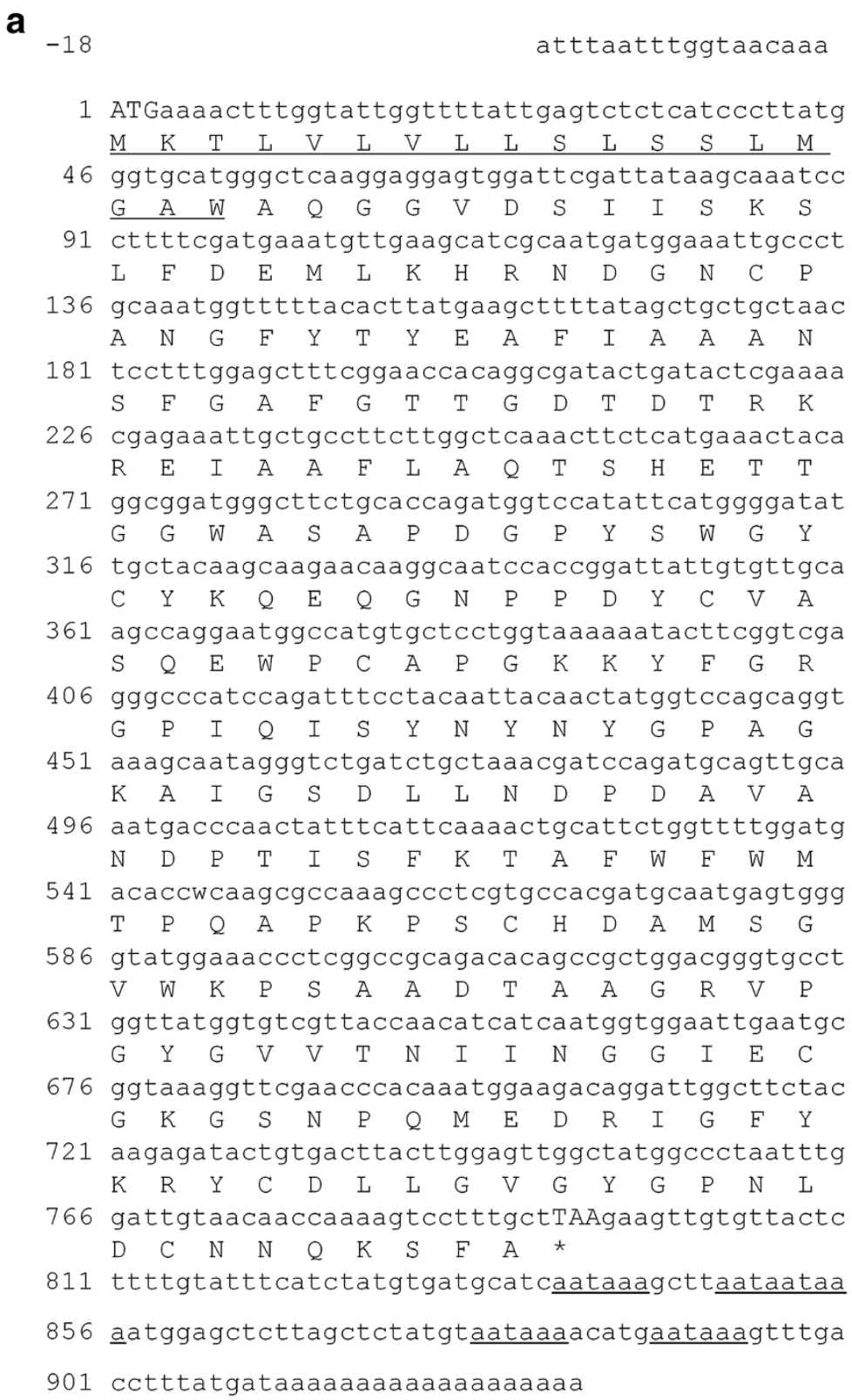

b

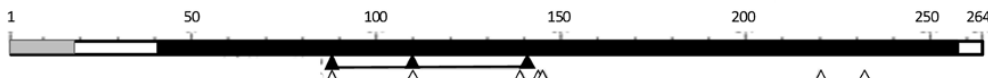

Figure 3 Primary structure of Oe-Chitinase I. (a) The nucleotide sequence of Oe-Chitinase I with its deduced amino acid sequence. The start and stop codons are in capital letters. The putative signal peptide at the N-terminus is doubly underlined. The five putative poly(A) additional signals are underlined. (b) A schematic representation of the Oe-Chitinase I protein showing the signal peptide (grey area), the catalytic domain of the chitinase-glycohydrolase 19 family (black area) and the positions of catalytic residues (black triangles) and putative sugar binding sites (white triangles).

that are highly conserved among members of the PR17 family of pathogenesis-related plant proteins [29] (Figure 6).

The transcriptional profile of these two genes was further investigated. We analysed the relative gene expression in fruits with $B$. oleae oviposition punctures or with feeding tunnels. Furthermore, we determined their response to wounding, one and two days after treatment (Figure 7). Considering that intraspecific variations in herbivory-induced signalling events and 
secondary metabolites exist among different plant populations [30], this work was performed in a different cultivated variety, 'Leccino'. Our results indicated that both Oe-Chitinase I and Oe-PR27 transcripts accumulate in response to fruit fly punctures and confirmed their strong activation in drupes with larval feeding tunnels. Furthermore, the wounding experiments showed that these genes are also inducible by mechanical damage. 


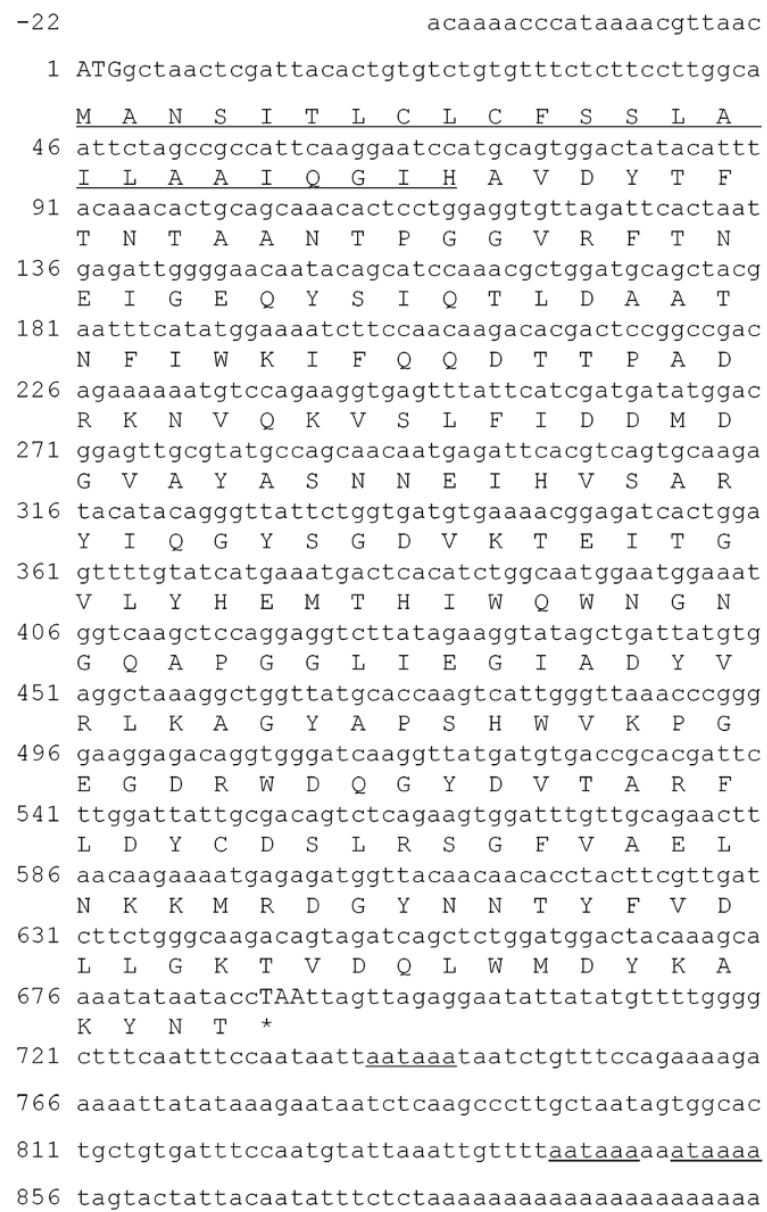

Figure 5 Primary structure of Oe-PRp27. The nucleotide sequence of Oe-PRp27 with its deduced amino acid sequence. The start and stop codons are in capital letters. The putative signal peptide at the $\mathrm{N}$-terminus is doubly underlined. The putative poly(A) additional signals are underlined.

Both genes had their higher transcriptional level at $24 \mathrm{~h}$ after treatment and interestingly, at this time-point, their level of expression of was similar to that recorded in olives punctured by the fruit fly. These data also suggest that other factors, most likely those related to the feeding habit of the larva, should be present to achieve the full induction of both genes in drupes with feeding tunnels.

\section{Identification of differentially expressed proteins}

A proteomic approach was used to ascertain the qualitative and quantitative modifications in the protein expression profile of olive fruits due to larval feeding. Protein extracts were prepared from infested and control fruits and subjected to 2-DE analysis. Software-assisted densitometric analysis of the resolved gels allowed a comparison of the respective proteomic repertoires. A representative Coomassie-stained gel from the control olives is shown in Figure 8. The average proteomic maps showed 578 (control fruits) and 498 (insect-infested fruits) spots, respectively, with a $77 \%$ similarity. The statistical evaluation $(p<0.05)$ of the relative spot densities detected 26 spots as differentially present in fruits subjected to larval attack, with at least a twofold difference with respect to the control. Eight spots showed increased abundance levels in insect-infested fruits, whereas the remainder exhibited the opposite trend. These spots were excised from the gels, digested with trypsin and subjected to nanoLC-ESI-LIT-MS/MS analysis. A database search with data deriving from the MS experiments allowed a positive identification of 23 spots. The list of the identified proteins is reported in the additional file 4 , together with their quantitative variations. For 19 spots, MS analysis demonstrated the occurrence of a single protein component within the analysed sample. Conversely, multiple polypeptide species $(2-3$ in number) were detected in each of the remaining 4 spots, as result of their concomitant electrophoretic migration. The identified sequences were compared against the available sequence databases to find similarities with known plant proteins; the entries with the highest scores are reported in the additional file 4. According to GO classification, the differentially expressed proteins are primarily involved in carbohydrate metabolism, redox processes and defence responses.

\section{Discussion}

In the SSH library approximately $40 \%$ of the unigenes identified in the SSH library could be functionally annotated. Although a comparison between different works is difficult because of the increasing number of sequences in the databases, this proportion is lower than those reported in similar works about model plant species $[16,18]$, yet it is similar to other reports on species whose genomes have not yet been sequenced [25,31]. Interestingly, the functional characterisation of the library indicated a higher representation of ESTs involved in the plant response to stress, including those related to biotic stress, such as wounding and pathogen attack, or abiotic stress, such as high or low temperature, drought and $\mathrm{NaCl}$. Moreover, we identified transcripts involved in the production, signal transduction or response to hormones and molecules (e.g., jasmonic acid and ROS) that are related to plant resistance to herbivorous pests. A similar number of sequences of the library matched uncharacterised olive transcripts, suggesting that the olive response to $B$. oleae also involves novel or undescribed genes. The functional annotation of the library showed that a critical barrier for working with the olive is the dependence on models of biochemical pathways, gene ontology repertoires and genomic information that are primarily based on model species [32]. These results 


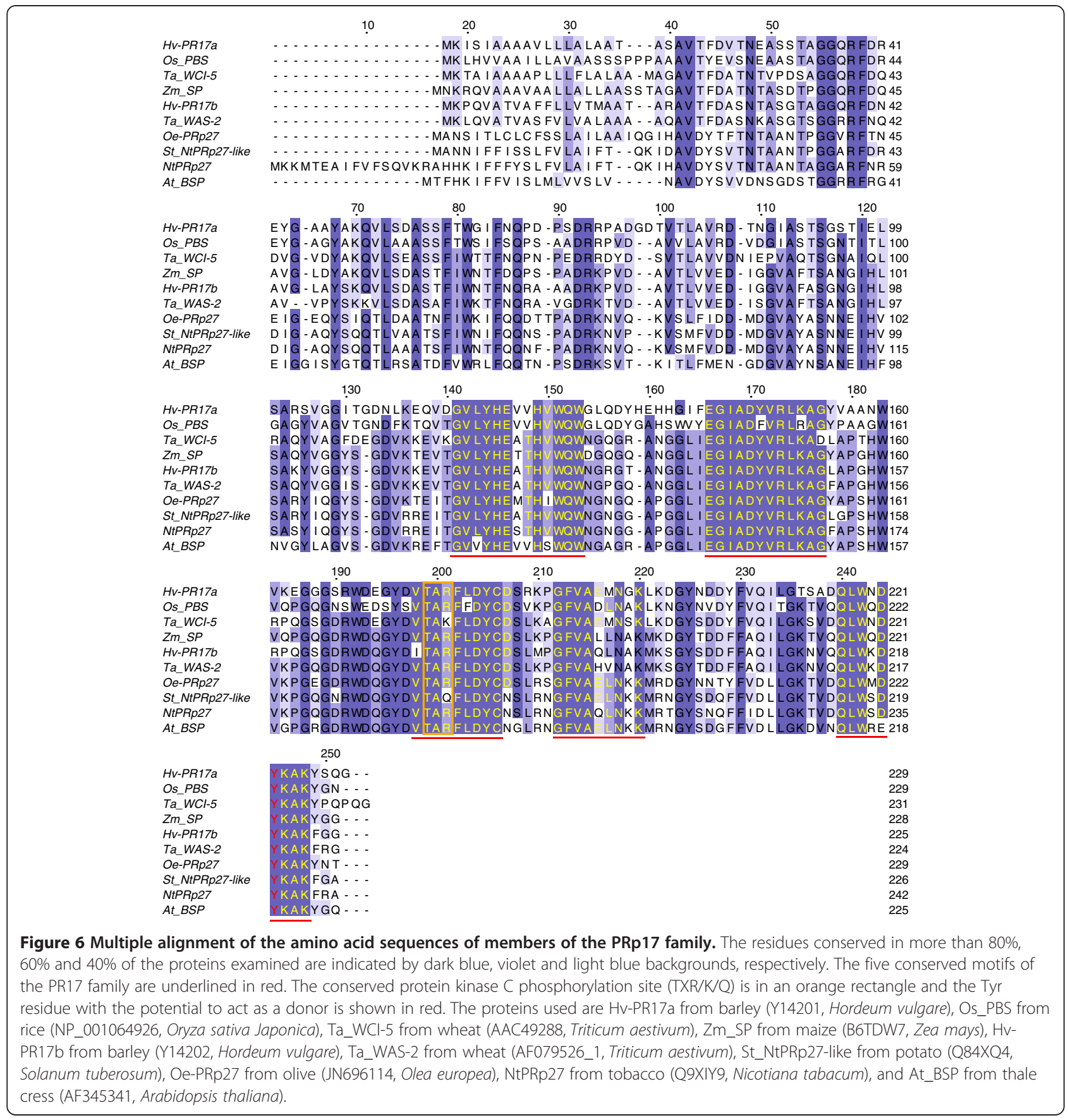

also demonstrated that the SSH approach was an appropriate strategy to study the olive response. Furthermore, although many cellular processes and pathways inherent to pest resistance are evolutionarily conserved in plants [30], the library analysis suggested that the plasticity of signal transduction networks and the variety of defence compounds may be particularly pronounced for olive. This assumption is conceivable, considering not only the difference between this tree and model plants but also the strong co-evolutionary relationship of the specialist
B. oleae with olive fruits. We anticipate that the uncharacterized unigenes may represent a reservoir of candidate defence genes and that their study may allow further insights into the mechanism of olive defence.

The proteomic analysis identified 19 proteins as differentially expressed after insect attack. Two of these entries were also identified in our transcriptomic dataset. As a percentage, the matching rate is similar to other studies based on the proteomic and transcriptomic analyses of non-model tree species [33-35]. Furthermore, 

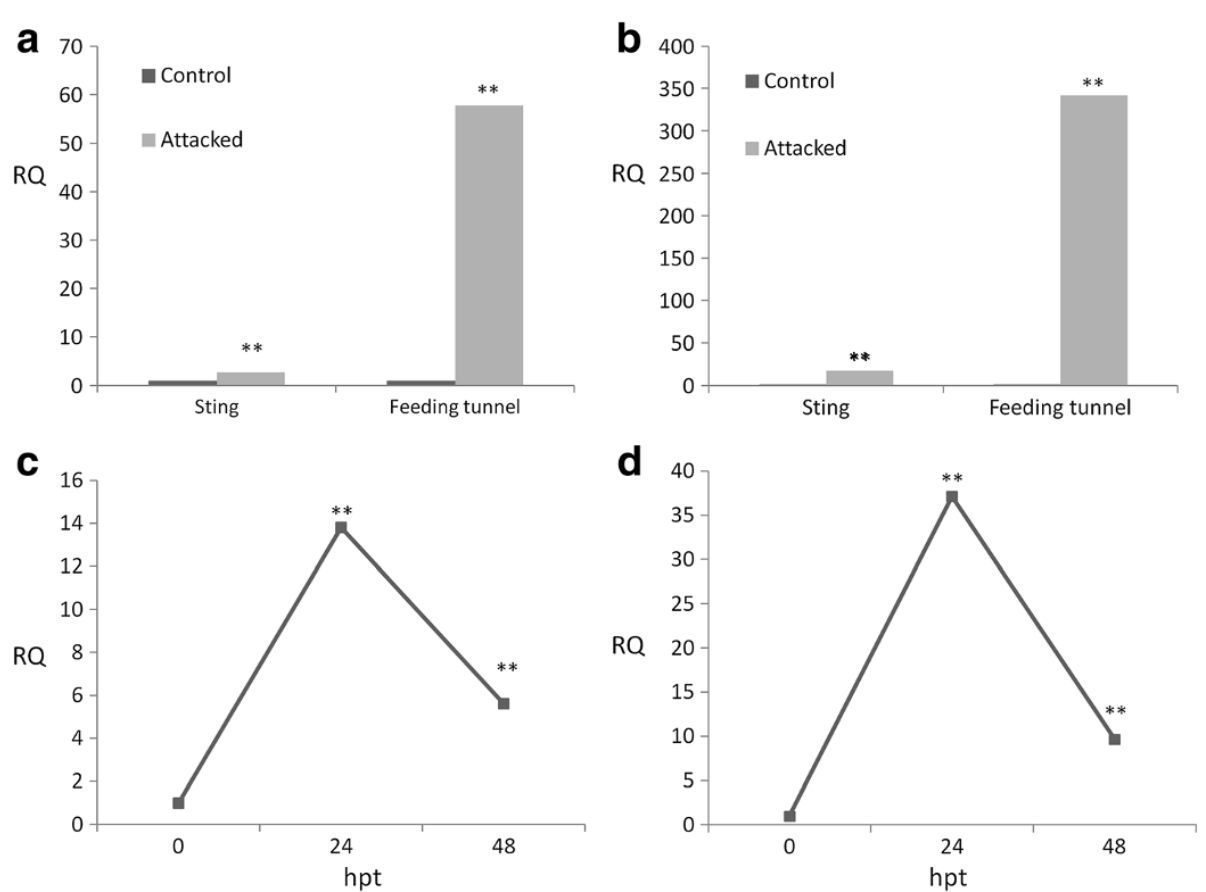

Figure 7 Real-time PCR analysis of the relative expression levels of the Oe-Chi I and Oe-PRp27 genes in relation to biotic and mechanical stress. RNA was isolated from drupes of the 'Leccino' cultivar. The graph displays the relative quantity (RQ) for each target gene (grey bars), shown on a linear scale relative to the calibrator (control drupes; white bars). Asterisks indicate significant difference compared to control $(p<0.01)$. a) The expression level of Oe-Chi I in drupes with oviposition punctures or larval feeding tunnels. b) The expression level of Oe-PRp27 I in drupes with oviposition punctures or larval feeding tunnels. c) A time-course of the expression level of Oe-Chi I in drupes following mechanical damage, at 0 (control), 24 and $48 \mathrm{~h}$ following treatment (hpt). d) A time-course of the expression level of Oe-PRp27 I in drupes at 0 (control), 24 and $48 \mathrm{~h}$ following treatment (hpt).

considering that the low correlation between sequences deriving from mRNA or protein analytical approaches is usually explained by post-transcriptional, translational and/or post-translational regulation processes [36,37], our data are suggestive of the importance and the

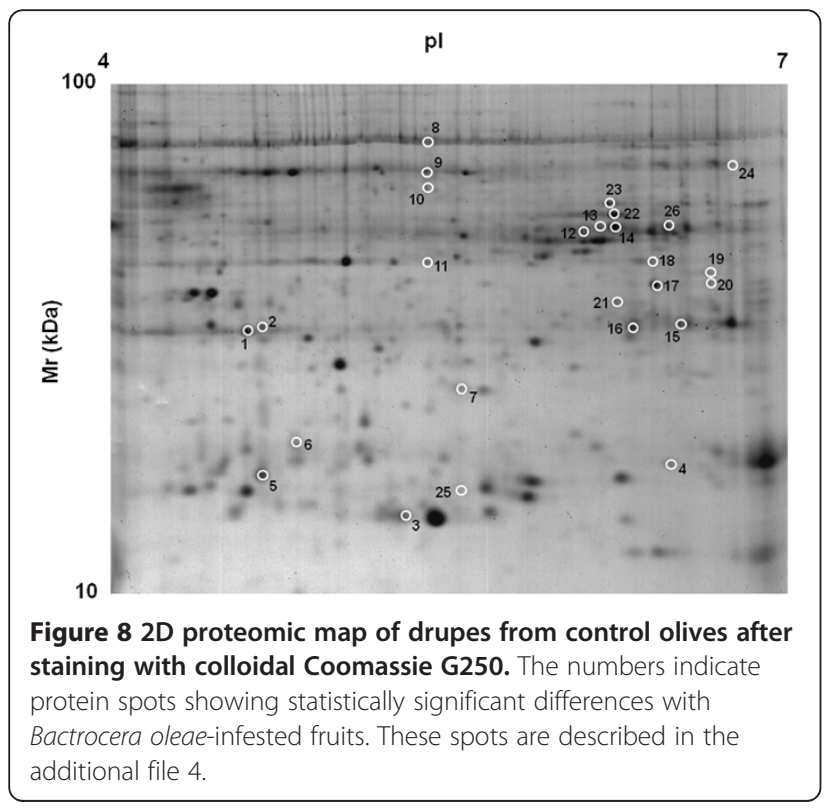

possible magnitude of post-transcriptional events for gene regulation during pest defence [38]. Finally, this comparison also shows that transcriptomic and proteomic data are complementary in plants, as in other organisms [39-43].

As plants present a variety of strategies against insects [30], it is expected that several molecular processes are involved in the defence mechanisms against the olive fruit fly. Functional annotation indicated that B. oleae larval feeding significantly diminished the abundance of various proteins related to photosynthesis and altered the amount of those related to carbohydrate metabolism, which included a reduced expression of serine hydroxymethyltransferase, which is important for photorespiration in mitochondria [44], and of enzymes related to carbohydrate catabolic processes. The downregulation of genes coding for photosynthetic proteins or the decline in the photosynthetic rate in attacked plants has been observed for different herbivores that feed on leaves [45]. It is interesting that we observed a similar effect on sink organs, thus supporting the proposition that primary metabolites could also function as signals in pest defence pathways [46]. A stress-related promotion of drupe maturation should also be taken into consideration [47]. Transcriptomic analysis also demonstrated that unigenes 
responding to stress represent the largest functional class of upregulated olive genes during B. oleae attack. Under this condition, proteomics revealed increased accumulation of beta-glucosidase (as transcriptomics), major latex proteins, which have been already reported as defensive proteins against insects $[48,49]$, phosphogluconolactonase and 6-phosphogluconate dehydrogenase. A possible defensive role of the latter enzymes has been suggested [50]. Taken together, the data indicated a metabolic shift towards defence during larval feeding [30]. Olive direct defence employs a variety of inducible factors, which include genes that are known to be important in the determination of the plant resistance to herbivorous pests, such as those coding for proteinase inhibitors or hydrolytic enzymes (e.g., chitinases and glucosidases); however, PR genes are also activated. Approximately one-third of the functionally annotated unigenes are homologues to genes first described to be involved in plant-pathogen interactions. Overlap in the signalling pathways regulating pathogen-plant and insect-plant interactions has been reported in several instances [51]. For the olive, such overlap is reasonable considering that $B$. oleae has long been known to be associated with different bacterial species [52,53].

The production of compounds involved in direct defence should be mainly dependent on a network that includes reactive oxygen species and phytohormone signalling. The results from the transcriptomic and proteomic analyses were consistent in showing a remarkable enrichment of genes and proteins involved in the regulation of the redox status (such as the metallothionein-like proteins, GST, catalase, thioredoxins, and aldo-keto reductase), thus indicating that ROS production should be a relevant component of induced olive defence. The reduction of some proteins involved ROS metabolism is indicative of the plant cell effort to maintain homeostasis under stress condition, preventing direct damage from the possible production of highly reactive cytotoxic compounds [54]. In the future, it will be interesting to ascertain if ROS production in drupes is also a consequence of the oxidative damage of membrane integrity due to lipid peroxidation. The functional classification indicated the presence of clones that are expected to be members of gene families involved in jasmonate signal transduction (e.g., lipoxygenase and the lipid transfer) or phenylpropanoid metabolism (i.e., the trans-cinnamate 4-hydroxylase and the Caffeoyl-o-methyltransferase) pathways, both of which produce compounds that, in plants, range from physical and chemical defence against biotic stressors to signal molecules involved in local and systemic signalling [55-57]. Overall, as was also reported for the interaction between the fungus S. oleaginea and olive [58], our data show an overlap of different pathways for the fruit fly response and denote that the olive responses to pathogens and herbivores should share a number of components at the signalling level [59].

Considering the unfeasibility of studying the olive-fruit fly interaction in controlled conditions, we recapitulated the expression analysis of twenty genes in drupes harvested in a different year. The real-time assay confirmed the differential expression of many but not all clones, as in other studies [32,60], implying that the extent of drupe responses to larval feeding may depend on the amount of damage inflicted, on environmental conditions at the time in which insects feed on plants, and on plant resource availability and allocation [11]. It is therefore relevant that, in replicate years and in two different cultivars, the most prominent gene activation was detected for trypsin inhibitors. Nonetheless, even though we could distinguish the transcripts of the two trypsin proteinase inhibitors in our qRT-PCR experiments, we cannot fully exclude the possibility that we monitored the activity of more than one transcript because serine inhibitors in plants belong to a large multigene family. In several plant species, proteinase inhibitors of the serine, cysteine and aspartic families are highly activated by larval feeding. Serine proteinases are the most relevant enzymes detected in the gut of Lepidoptera, Coleoptera, Hemiptera, Homoptera and Diptera [61]. However, bioassays using serine protease inhibitors against Diptera are more limited than in other insect orders. It has been shown that the gut proteolytic systems of larvae of the Mediterranean fruit fly (C. capitata) rely mostly on basic proteinases, with trypsin-like serine proteinases being the most important [62]. For these reasons, we argue that trypsin inhibitors should be a major element of drupe defence reaction. An in vivo assay against the olive fruit fly using purified inhibitors would clarify whether these molecules could be established as a novel insect control strategy, based on biocompounds, on targeting the production of insect digestive enzymes by RNAi [63], on the selection of highly expressing olive genotypes, and on their combination.

Among the SSH-enriched cDNA clones, two sequences, coding for a chitinase and a PRp27-like protein, were selected for further functional characterisation. We isolated their full-length cDNA and studied their expression in response to biological (adult puncture and larval feeding of B. oleae) and physical (mechanical wounding) stress.

The Oe-Chi I protein has the two signature motifs of family 19 of the chitinases. Chitinases have long been considered a significant component of plant defence because of their direct action against chitin-containing pestiferous and pathogenic organisms. Furthermore, some of these enzymes are also involved in developmental processes or are associated with abiotic stress. The presence of a putative signal peptide and the gene 
expression analysis strongly support a role in drupe defence for Oe-Chi I. Specifically, taking into account the magnitude of gene activation, it is tempting to speculate that Oe-Chi I may not be exclusively involved in biological processes activated by "generic" mechanical damage but that this gene plays a specific role in the onset of the reaction against larval feeding. Although chitinases in plants are primarily associated with fungal resistance, there are various reports documenting their activation in plants following pest attack [64]. Interestingly, a chitinase was found to be specifically activated by the application of Colorado beetle regurgitant, and the gene had the highest expression level after a continuous infestation [65]. Further work, primarily directed towards the characterisation of the Oe-Chi I protein product, will be performed to understand its possible effect against phytophagous pests $[66,67]$.

The Oe-PRp27 gene was named after its high similarity to the Nicotiana tabacum NtPRp27, which codes for a secreted protein belonging to the Pathogenesis-Related 17 (PR17) family [29]. Homologues of NtPRp27 have been found in a wide variety of flowering plants and because of their transcriptional activation in response to pathogen infection and various elicitors, these genes are classified as encoding PR proteins. However, the roles of the members of the PR17 family have not been fully elucidated, especially because these genes are activated by various forms of stress (drought, wounding, ABA, ethylene and MeJA) [68], and their constitutive expression in transgenic plants does not necessarily lead to an increased resistance to pathogens $[29,69]$. It has been proposed that PR17 members may act in defence responses with relation to either cell wall metabolism or signal transduction [29], which would be consistent with the rapid activation of Oe-PR27 after wounding. Furthermore, Oe-PR27 is induced by $B$. oleae feeding and punctures, implying an involvement in insect defence. This result is not completely unexpected, as NtPR27 is also induced by JA and ethylene [70], and recently, the accumulation of an NtPR-like protein was reported during bacterial infection of grape [71]. Although the mode of action and specificity of the PR17 family remain to be determined [68], our data support a possible broad function of members of this group in the early stages of defence, rather than as antibiotic components directly acting against invading pathogens.

\section{Conclusion}

This study is the first investigation of the transcriptome and proteome of olive drupes attacked by B. oleae. The data from complementary approaches were useful to allow the identification of molecular players and to outline the biological functions, cellular processes and pathways associated with the drupe defence reaction. This work also revealed interesting genes that could have important roles in olive resistance and, eventually, be useful for the development of novel control strategies.

\section{Methods}

\section{Suppression subtractive hybridization (SSH) library construction}

Control and infested fruits of the olive (Olea europaea L. var. 'europaea') cultivar 'Moraiolo' were harvested (110 days after flowering) from plants growing in Montefalco (Perugia, Italy). The larvae were manually removed from the infested fruits and visually inspected under a binocular microscope, and tissues were stored at $-80^{\circ} \mathrm{C}$ until molecular analysis. We found and analysed fruits with one larva. Biological replicates of the same variety were obtained from the Olive Cultivar Collection held by the 'Centro di Ricerca per l'Olivicoltura e l'Industria Olearia' in Collececco (Spoleto, Perugia, Italy). The fruit tissue surrounding the feeding tunnels of third instar larvae was used for library construction. Total RNA was isolated using the RNeasy Plant Mini Kit (Qiagen, Milano, Italy), and the contaminating genomic DNA was removed by a DNase I (Qiagen) treatment, according to the manufacturer's instructions. PolyA + mRNA was isolated using Dynabeads Oligo $(\mathrm{dT})_{25}$ (Invitrogen, Milano, Italy), and cDNA synthesis and subtracted library preparation were conducted with the PCR-select cDNA Subtraction Kit (Clontech, Milano, Italy), according to the manufacturer's instructions. The tester and driver libraries were prepared from $4.0 \mu \mathrm{g}$ of polyA + mRNA of infested and control undamaged fruits, respectively. The subtractive PCR experiments were conducted after 27 cycles of primary PCR and 11 cycles of secondary PCR with Advantage cDNA Polymerase mix (Clontech).

\section{SSH library analysis}

Blunt-end PCR products were cloned in pCR-Blunt IITOPO plasmid vector (Blunt TOPO PCR Cloning Kit; Invitrogen) according to the manufacturer's protocol. Following blue-white selection [72], the colonies were chosen at random and re-plated on selective medium for subsequent analysis. Plasmid DNA was isolated from an overnight culture in liquid selective medium using a standard alkaline lysis procedure [72]. The presence and size of the insert were verified by restriction digestion using Eco RI (Promega, Milano, Italy). Sanger sequencing was performed using the M13 forward and reverse primers with the BigDye Terminator v. 3.1 Ready Reaction Cycle Sequencing Kit (Applied Biosystems, Milano, Italy). After reaction clean-up using the BigDye XTerminator Purification Kit (Applied Biosystems), the fragments were resolved and analysed in an Applied Biosystems 3130 sequencer at the GenoPom Laboratory 
(Portici, Napoli, Italy). The vector backbone and adapter sequences were trimmed manually. The clones were filtered to eliminate sequences with low-quality reads, repeats (including low-complexity DNA sequences and highly repetitive sequences), low information content (such as runs of a single amino acid or a few amino acids, or runs of pyrimidines or purines), or sizes smaller than 66 bp. To remove redundancy for subsequent bioinformatic analysis, we assembled ESTs to obtain unigenes, using the CAP3 software with the default parameters [73]. The redundancy of the library was then calculated according to the following formula: [number of sequences - (total number of contiguous + total number of singletons)]/(total number of sequences)]*100.

Singletons and assembled DNA sequences (unigenes) were compared against non-redundant nucleotide and protein databases at the National Center for Biotechnological Information (www.ncbi.nlm.nih.gov) using BLAST programs [74]. First, comparative analysis was performed against non-redundant protein database with blastX. For clones showing low similarity, the comparison was conducted with blastn against the non-redundant nucleotide database, the nucleotide Expressed Sequence Tag database (dbEST) and, finally, the OleaESTdb (http://www.oleadb.it/). Potential open reading frames (ORFs) were searched using the Expasy translate tool [75]. As olive is a 'non-model' species, a low e-value threshold was used to determine whether a BLAST similarity allowed for functional annotation transfer to our unigenes. We retrieved the Gene Ontology (GO) terms associated with the Blast hits considering informative sequences with an e-value lower than 1e-06. The GO annotation was conducted using the Blast2GO software [76] at the default parameters, generating a 'Plant' GO-Slim mapping for the available annotations with a cut-off of two sequences. Conserved domains were searched in the predicted protein sequence database (http://www.ncbi.nlm.nih. gov/Structure/cdd/wrpsb.cgi) [77]. Subcellular localisation prediction was performed using the TargetP software (http://www.cbs.dtu.dk/services/TargetP) [78]. The iPSORT software was used to predict Signal Peptides in protein sequences [79].

\section{Real time PCR}

For the transcriptional study of gene expression by realtime PCR, control and infested fruits of the olive cultivar 'Moraiolo' were harvested 110 days after flowering from plants growing in Montefalco (Perugia, Italy). One microgram of total RNA, isolated as described above, was treated with DNAse I (New England Biolabs, Milano, Italy) and reverse-transcribed with the RevertAid First Strand cDNA Synthesis Kit (Fermentas, Milano, Italy). The RNA quantity and quality were estimated spectrophotometrically (Biophotometer, Eppendorf, Milano, Italy). The PCR primers used in the qRT-PCR expression studies were designed using the Primer Express 2.0 software (Applied Biosystems). The primers and the sizes of the expected amplicons are indicated in the additional file 5. The amplification of the cDNA coding for the Elongation Factor 1- $\alpha$ gene (Acc. Num. AM946404.1) served as a control for cDNA synthesis and PCR efficiency in the different samples. The sequences annealed by the two primers EF1-For and EF1-Rev are localised in two contiguous exons for the detection of possible contaminant DNA in the PCR amplifications. The real-time PCR experiments were performed using the ABI PRISM 7900HQ Sequence Detection System (Applied Biosystems, Foster City, CA, USA) as described [80]. Three independent amplifications were performed for each cDNA sample, and the reactions were performed for two biological replicates. The thermal cycling program started with a step of 2 min at $50^{\circ} \mathrm{C}$ and $10 \mathrm{~min}$ at $95^{\circ} \mathrm{C}$, followed by 35 cycles consisting of $15 \mathrm{sec}$ at $95^{\circ} \mathrm{C}$ followed by $1 \mathrm{~min}$ at $58^{\circ} \mathrm{C}$. After each assay, a dissociation kinetics analysis was performed to check the specificity of the amplification products. The reaction products were also resolved on an agarose gel to verify the amplicon size. The relative quantification of the gene expression and its statistical test was conducted as previously described [81].

\section{Random amplification of cDNA ends (RACE) PCR}

The recovery of full-length CDNA was performed by $5^{\prime}$ and 3' rapid amplification of cDNA ends, using the 5' RACE System for Rapid Amplification of cDNA Ends (Invitrogen) and the 3' RACE System for Rapid Amplification of cDNA Ends (Invitrogen), according to the manufacturer's instructions. Briefly, for the 5' RACE, $5 \mu \mathrm{g}$ of total RNA were reverse-transcribed using the SuperScript II enzyme (Invitrogen) and $0.5 \mu \mathrm{g}$ of gene specific primer for $2 \mathrm{~h}$, at $42^{\circ} \mathrm{C}$. The sequences of the Oe-PRp27 and OeChi I primers were 5'-GGAGCTTGACCATTTCCA-3' and 5'-CCAATCCTGTCTTCCATTTG-3', respectively. Second-strand cDNA synthesis was performed using the Abridged Universal Amplification Primer (Invitrogen) with the oligo $5^{\prime}$-TGATCTCCGTTTTCACATCACCA for Oe-PRp27 or 5' -GTTCGAACCTTTACCGCATTCAA for Oe-Chi I. The amplification conditions were one cycle of $94^{\circ} \mathrm{C}$ for $3 \mathrm{~min} ; 40$ cycles of $94^{\circ} \mathrm{C}$ for $30 \mathrm{sec}, 55^{\circ} \mathrm{C}$ for $1 \mathrm{~min}$ and $72^{\circ} \mathrm{C}$ for $2 \mathrm{~min}$; and a final step of $72^{\circ} \mathrm{C}$ for $10 \mathrm{~min}$. For the $3^{\prime} \mathrm{RACE}$, the total RNA was retrotranscribed as above, using $0.5 \mu \mathrm{g}$ of Adapter Primer (Invitrogen). The PCR amplification was conducted with either the Oe-PR27 gene-specific primer (5'ATGTTTTGGGGCTTTCAATTTCC) or the Oe-Chi primer (5' - CCAACATCATCAATGGTGGA) along with the AUAP. The cycling conditions were as described 
above, except that the annealing temperature was $58^{\circ} \mathrm{C}$. The PCR products were gel-purified using the QIAquick Gel Extraction Kit (Qiagen) and cloned into the pGEM-T Easy vector (Promega) according to the manufacturers' instructions. The selection of recombinant colonies, plasmid DNA isolation and sequencing were performed as described above.

\section{Wounding treatment}

Control and treated fruits of the olive cultivar 'Leccino' were treated 110 days after flowering. Drupes (of approximately $1.5 \mathrm{~cm}$ ) were diagonally punctured (10 times) with a sterile steel needle without damaging the stone. Samples were harvested at time 0 (control), 24 and $48 \mathrm{~h}$ following treatment. Two pools of five drupes per plant were harvested from three separate branches. The drupes were manually destoned and frozen in liquid nitrogen until RNA isolation. The experiments were conducted in duplicate using drupes harvested from different trees.

\section{Protein extraction and 2-D electrophoresis}

Drupes of three biological replicates of infested or control fruits from the cv. 'Moraiolo' were harvested at the same time, prepared and stored as described for the SSH library. Each biological replicate was independently subjected to a modified double protein extraction [82]. Briefly, $2.5 \mathrm{~g}$ of pulp were finely powdered in liquid nitrogen and suspended in $15 \mathrm{ml}$ of ice-cold $10 \%$ trichloroacetic acid in acetone. After centrifugation at $10,000 \mathrm{~g}$, for $5 \mathrm{~min}$, at $4^{\circ} \mathrm{C}$, the pellet was suspended in $10 \mathrm{ml}$ of ice-cold $80 \%$ ammonium acetate in methanol and centrifuged as above. The pellet was suspended in $10 \mathrm{ml}$ of ice-cold $80 \%$ acetone, centrifuged as above and resuspended in $7.5 \mathrm{ml}$ of extraction buffer (30\% sucrose, 2\% SDS, 2\% w/v $\beta$-mercaptoethanol, $1 \mathrm{mM}$ PMSF, $1 \mathrm{mM}$ Protease Inhibitor Cocktail (Sigma, Milano, Italy), 0.1 M Tris-HCl; pH 8.0). After addition of an equal volume of saturated phenol in $500 \mathrm{mM}$ Tris- $\mathrm{HCl}, \mathrm{pH} 7.5$, the mixture was stirred for $10 \mathrm{~min}$ and then centrifuged at $10,000 \mathrm{~g}$, for $15 \mathrm{~min}$, at $4^{\circ} \mathrm{C}$. The upper phenol phase was removed and extracted twice with the extraction buffer. Proteins were recovered from the phenol phase by addition of $5 \mathrm{vol}$ of saturated ammonium acetate in methanol, overnight, at $-20^{\circ} \mathrm{C}$, and centrifuged at $10,000 \mathrm{~g}$, for $30 \mathrm{~min}$. Protein samples were then stored at $-80^{\circ} \mathrm{C}$.

Protein extracts were washed once with ice-cold methanol and three times with ice-cold acetone, dried under reduced pressure and dissolved in IEF buffer $(9 \mathrm{M}$ urea, $4 \% \mathrm{w} / \mathrm{v}$ CHAPS, $0.5 \% \mathrm{v} / \mathrm{v}$ Triton X-100, $20 \mathrm{mM}$ DTT, $1 \% \mathrm{w} / \mathrm{v}$ carrier ampholytes pH 3-10, Bio-Rad, Hercules, CA, USA). Protein concentration was calculated by using the Bio-Rad protein assay, with BSA as a standard. IPG strips (17 cm, pH 5-8, ReadyStrip) (BioRad) were rehydrated overnight with $300 \mu$ of IEF buffer containing $400 \mu \mathrm{g}$ of total proteins. Proteins were focused using a Protean IEF Cell (Bio-Rad) at $12^{\circ} \mathrm{C}$ as described [83]. After focusing, the proteins were reduced by incubating the IPG strips with $1 \% \mathrm{w} / \mathrm{v}$ DTT, for $15 \mathrm{~min}$, and alkylated with $2.5 \% \mathrm{w} / \mathrm{v}$ iodoacetamide in $10 \mathrm{ml}$ of equilibration buffer (6 M urea, 30\% w/v glycerol, 2\% w/v SDS, $50 \mathrm{mM}$ Tris- $\mathrm{HCl} \mathrm{pH} \mathrm{8.8,} \mathrm{and} \mathrm{a} \mathrm{dash}$ of bromophenol blue) for $15 \mathrm{~min}$. Electrophoresis in the second dimension was carried out on $12 \%$ polyacrylamide gels $(180 \times 240 \times 1 \mathrm{~mm})$ with the Protean apparatus (Bio-Rad), using electrophoresis buffer $(1 \% \mathrm{w} / \mathrm{v}$ SDS, $1.92 \mathrm{M}$ glycine, $25 \mathrm{mM}$ Tris- $\mathrm{HCl}, \mathrm{pH} 8.3)$, with $120 \mathrm{~V}$ applied for $12 \mathrm{~h}$, until the dye front reached the bottom of the gel. Gels were stained with colloidal Coomassie G250. Each biological replicate from infested or control fruits was run in triplicate. Gel image acquisition and analysis was performed as described [83]. After normalization of the spot densities against the whole-gel densities, the percentage volume of each spot was averaged for nine different (three technical replicates of three biological samples) gels [24,35]. A two-fold change in normalized spot densities was considered indicative of a differentially synthesized protein (Student's $t$-test).

\section{In gel digestion, mass spectrometry analysis and protein identification}

Spots were excised from gels, triturated, in-gel reduced, S-alkylated and digested with trypsin, as previously reported [84]. Digests were subjected to desalting on ZipTipC18 (Millipore, Bedford, MA, USA), using 5\% formic acid $/ 50 \%$ acetonitrile as eluent, and analyzed by nanoLC-ESI-LIT-MS/MS with a LTQ XL mass spectrometer (Thermo, San Jose, CA, USA) equipped with Proxeon nanospray source connected to an EasynanoLC (Proxeon, Odense, Denmark) [85]. Peptide mixtures were separated on an Easy C18 column $(10 \times 0.075 \mathrm{~mm}, 3 \mu \mathrm{m})$ (Proxeon) by using a linear gradient from $5 \%$ to $50 \%$ of acetonitrile in $0.1 \%$ formic acid, over $60 \mathrm{~min}$, at a flow rate of $300 \mathrm{nl} / \mathrm{min}$. Spectra were acquired in the range $\mathrm{m} / \mathrm{z} 400-2000$. Acquisition was controlled by a data-dependent product ion scanning procedure over the three most abundant ions, enabling dynamic exclusion (repeat count 2 and exclusion duration $1 \mathrm{~min}$ ). The mass isolation window and collision energy were set to $m / z 3$ and $35 \%$, respectively.

MASCOT software package (Matrix Science, UK) was used to identify spots unambiguously from either an updated database containing all O. europea ESTs available over the WEB, or a plant non-redundant sequence database (NCBI nr 2009/05/03). Data were searched by using a mass tolerance value of $2 \mathrm{Da}$ for precursor ion and $0.8 \mathrm{Da}$ for MS/MS fragments, trypsin as proteolytic 
enzyme, a missed cleavages maximum value of 2 and Cys carbamidomethylation and Met oxidation as fixed and variable modification, respectively. Candidates with more than 2 assigned peptides with an individual MASCOT score $>25$, corresponding to $p<0.05$ for a significant identification, were further evaluated by the comparison with their calculated mass and pI values, using the experimental values obtained from 2-DE.

\section{Additional files}

\section{Additional file 1: Candidate genes isolated from the SSH library. Additional file 2: BlastN similarity of the SSH clones to nucleotide sequences.}

Additional file 3: The real-time PCR analysis of the expression level of the Trypsin inhibitor II transcripts in the olive cultivar 'Leccino'. The graph displays the relative quantification of the gene expression (RQ) in drupes with feeding tunnels (infested) relative to uninfested drupes (control), set as the calibrator. Asterisks indicate significant difference compared to control $(p<0.01)$.

Additional file 4: Proteins with changed expression levels in 0. europaea fruits after damage by Bactrocera oleae. The spot number, protein name, gene/EST number according to the NCBI database, protein entry in the NCBI database with the highest BLAST score, experimental $\mathrm{pl} / \mathrm{Mr}$ values, peptide number/sequence coverage (\%), Mascot score, identification method, organism, fold change for infested vs. control plants and GO classification are listed. All of the spots were identified by tandem MS.

Additional file 5: Primers used for the expression study and their main features.

\section{Abbreviations}

EST: Expressed Sequence Tag; MS: Mass Spectrometry; ORF: Open Reading Frames; PR: Pathogenesis-Related; qRT-PCR: quantitative Real-Time PCR; RACE: Random Amplification of cDNA Ends; ROS: Reactive Oxygen Species; SSH: Suppression Subtractive Hybridisation.

\section{Competing interests}

The authors declare that they have no competing interests.

\section{Authors' contribution}

GC designed experiments, analysed the data and wrote the paper, FA performed gene expression analysis, RACE-PCRs and GO analysis, MR and GR performed the proteomic work, PV constructed subtractive libraries, VC performed the experiments of the wounding assay and provided assistance in the $\mathrm{GO}$ analysis, $\mathrm{MC}$ was involved in the $\mathrm{GO}$ analysis, $\mathrm{AG}$ provided expertise in the classification of harvested material, LB provided plant material and participated in the study design, AS analysed the proteomic data, RR conceived and designed the study and reviewed the manuscript. All authors read and approved the manuscript.

\section{Acknowledgments}

This work was supported by Ministero delle Politiche Agricole, Alimentari e Forestali, Project OLEA: Olive genomic and Breeding, activity 8.1 'Tolerance to biotic stresses'. The proteomic activity was supported by a dedicated grant from the Italian Ministry of Economy and Finance to CNR and ENEA for the project "Innovazione e sviluppo del Mezzogiorno - Conoscenze Integrate per Sostenibilità ed Innovazione del Made in Italy Agroalimentare" - Legge n.191/2009 to A.S. The Authors thank Dr. Annalisa Imperato for her assistance during the preparation of the library and the sequencing of plasmid DNA.

\section{Author details}

'Dipartimento di Scienze del Suolo, Pianta, Ambiente e Produzioni Animali, Universita' degli Studi di Napoli Federico II, Via Università 100, Portici, Napoli 80055, Italy. Istituto di Genetica Vegetale, Consiglio Nazionale delle Ricerche,
Via della Madonna Alta 130, Perugia 06128, Italy. ${ }^{3}$ Dipartimento di Scienze per la Biologia, la Geologia e l'Ambiente, Universita' del Sannio, Via dei Mulini 59/A, Benevento 82100, Italy. ${ }^{4}$ Istituto per il Sistema Produzione Animale in Ambiente Mediterraneo, Consiglio Nazionale delle Ricerche, Via Argine 1085, Napoli 80147, Italy. ${ }^{5}$ Dipartimento di Entomologia e Zoologia Agraria "F. Silvestri", Universita' degli Studi di Napoli Federico II, Via Università 100, Portici 80055, Italy.

Received: 6 March 2012 Accepted: 22 May 2012

Published: 13 June 2012

\section{References}

1. Daane KM, Johnson MW: Olive Fruit Fly: Managing an ancient pest in modern times. Ann Rev Entomol 2010, 55:151-169.

2. Burrack HJ, Connell JH, Zalom FG: Comparison of olive fruit fly (Bactrocera oleae (Gmelin)) (Diptera: Tephritidae) captures in several commercial traps in California. Int J Pest Manag 2008, 54(3):227-234.

3. Skouras PJ, Margaritopoulos JT, Seraphides NA, loannides IM, Kakani EG, Mathiopoulos KD, Tsitsipis JA: Organophosphate resistance in olive fruit fly, Bactrocera oleae, populations in Greece and Cyprus. Pest Manag Sci 2007, 63(1):42-48.

4. Koprivnjak O, Dminic I, Kosic U, Majetic V, Godena S, Valencic V: Dynamics of oil quality parameters changes related to olive fruit fly attack. Europ $J$ Lip Sci Tech 2010, 112(9):1033-1040.

5. Nardi F, Carapelli A, Dallai R, Roderick GK, Frati F: Population structure and colonization history of the olive fly, Bactrocera oleae (Diptera, Tephritidae). Mol Ecol 2005, 14(9):2729-2738.

6. Hawkes NJ, Janes RW, Hemingway J, Vontas J: Detection of resistanceassociated point mutations of organophosphate-insensitive acetylcholinesterase in the olive fruit fly, Bactrocera oleae (Gmelin). Pest Biochem Physiol 2005, 81(3):154-163.

7. Vontas JG, Hejazi MJ, Hawkes NJ, Cosmidis N, Loukas M, Hemingway J: Resistance-associated point mutations of organophosphate insensitive acetylcholinesterase, in the olive fruit fly Bactrocera oleae. Insect Mol Biol 2002, 11(4):329-336.

8. Loscalzo R, Scarpati ML, Verzegnassi B, Vita G: Olea europaea chemicals repellent to Dacus oleae females. J Chem Ecol 1994, 20(8):1813-1823.

9. Scarpati ML, LoScalzo R, Vita G, Gambacorta A: Chemiotropic behavior of female olive fly (Bactrocera oleae gmel) on Olea europaea L. J Chem Ecol 1996, 22(5):1027-1036.

10. Iannotta N, Perri I, Tocci C, Zaffina F: The behaviour of different olive cultivars following attacks by Bactrocera oleae (Gmel.) III International Symposium on Olive Growing. Acta Horticol 1999, 474:545-548.

11. Massei G, Hartley SE: Disarmed by domestication? Induced responses to browsing in wild and cultivated olive. Oecologia 2000, 122(2):225-231.

12. Wang XG, Nadel H, Johnson MW, Daane KM, Hoelmer K, Walton VM, Pickett $\mathrm{CH}$, Sime KR: Crop domestication relaxes both top-down and bottom-up effects on a specialist herbivore. Basic Appl Ecol 2009, 10(3):216-227.

13. Diatchenko L, Lau YFC, Campbell AP, Chenchik A, Mogadam F, Huang B, Lukyanov S, Lukyanov K, Gurskaya N, Sverdlov ED, et al: Suppression subtractive hybridization: A method for generating differentially regulated or tissue-specific cDNA probes and libraries. P Natl Acad Sci USA 1996, 93(12):6025-6030.

14. Schittko U, Hermsmeier D, Baldwin IT: Molecular interactions between the specialist herbivore Manduca sexta (Lepidoptera, Sphingidae) and its natural host Nicotiana attenuata. II. Accumulation of plant mRNAs in response to insect-derived cues. Plant Physiol 2001, 125(2):701-710.

15. Estrada-Hernandez MG, Valenzuela-Soto JH, Ibarra-Laclette E, Delano-Frier JP Differential gene expression in whitefly Bemisia tabaci-infested tomato (Solanum lycopersicum) plants at progressing developmental stages of the insect's life cycle. Physiol Plantarum 2009, 137(1):44-60.

16. Jin $H C$, Sun $Y$, Yang $Q C$, Chao $Y H$, Kang JM, Jin $H$, Li Y, Margaret G: Screening of genes induced by salt stress from Alfalfa. Mol Biol Reports 2010, 37(2):745-753.

17. Johnson $L$, Johnson RD, Schardl CL, Panaccione DG: Identification of differentially expressed genes in the mutualistic association of tall fescue with Neotyphodium coenophialum. Physiol Mol Plant Pathology 2003, 63(6):305-317.

18. Ouyang B, Yang T, Li HX, Zhang L, Zhang YY, Zhang JH, Fei ZJ, Ye ZB: Identification of early salt stress response genes in tomato root by 
suppression subtractive hybridization and microarray analysis. $J$ Exper Botany 2007, 58(3):507-520.

19. Huang XW, Li YX, Niu QH, Zhang KQ: Suppression Subtractive Hybridization (SSH) and its modifications in microbiological research. Appl Microbiol Biotech 2007, 76(4):753-760.

20. Dani V, Simon WJ, Duranti M, Croy RRD: Changes in the tobacco leaf apoplast proteome in response to salt stress. Proteomics 2005, 5(3):737-745.

21. Jones AME, Thomas V, Bennett MH, Mansfield J, Grant M: Modifications to the arabidopsis defense proteome occur prior to significant transcriptional change in response to inoculation with Pseudomonas syringae. Plant Physiol 2006, 142(4):1603-1620

22. Collins RM, Afzal M, Ward DA, Prescott MC, Sait SM, Rees HH, Tomsett AB: Differential proteomic analysis of Arabidopsis thaliana genotypes exhibiting resistance or susceptibility to the insect herbivore Plutella xylostella. PLoS One 2010, 5(4):e10103.

23. Kjellsen TD, Shiryaeva L, Schroder WP, Strimbeck GR: Proteomics of extreme freezing tolerance in Siberian spruce (Picea obovata). $J$ Proteomics 2010, 73(5):965-975.

24. Huang C, Verrillo F, Renzone G, Arena S, Rocco M, Scaloni A, Marra M: Response to biotic and oxidative stress in Arabidopsis thaliana: Analysis of variably phosphorylated proteins. J Proteomics 2011, 74(10):1934-1949.

25. Paux E, Tamasloukht M, Ladouce N, Sivadon P, Grima-Pettenati J: Identification of genes preferentially expressed during wood formation in Eucalyptus. Plant Mol Biol 2004, 55(2):263-280.

26. Irles $P$, Belles $X$, Piulachs MD: Identifying genes related to choriogenesis in insect panoistic ovaries by Suppression Subtractive Hybridization. BMC Genomics 2009, 10:206-218.

27. Spadafora A, Mazzuca S, Chiappetta FF, Parise A, Perri E, Innocenti AM: Oleuropein-Specific-beta-Glucosidase Activity Marks the Early Response of Olive Fruits (Olea europaea) to Mimed Insect Attack. Agricul Sci China 2008, 7(6):703-712

28. Rajeevan MS, Ranamukhaarachchi DG, Vernon SD, Unger ER: Use of realtime quantitative PCR to validate the results of CDNA array and differential display PCR technologies. Methods 2001, 25(4):443-451.

29. Christensen AB, Cho BH, Naesby M, Gregersen PL, Brandt J, MadrizOrdenana $\mathrm{K}$, Collinge DB, Thordal-Christensen $\mathrm{H}$ : The molecular characterization of two barley proteins establishes the novel PR-17 family of pathogenesis-related proteins. Mol Plant Pathol 2002, 3(3):135-144.

30. Wu JQ, Baldwin IT: New insights into plant responses to the attack from insect herbivores. Annu Rev Genet 2010, 44:1-24.

31. Hermsmeier D, Schittko U, Baldwin IT: Molecular interactions between the specialist herbivore Manduca sexta (Lepidoptera, Sphingidae) and its natural host Nicotiana attenuata. I. Large-scale changes in the accumulation of growth- and defense-related plant mRNAs. Plant Physiol 2001, 125(2):683-700.

32. Kultz D, Fiol D, Valkova N, Gomez-Jimenez S, Chan SY, Lee J: Functional genomics and proteomics of the cellular osmotic stress response in 'non-model' organisms. J Exp Biol 2007, 210(9):1593-1601.

33. Gion JM, Lalanne C, Le Provost G, Ferry-Dumazet H, Paiva J, Chaumeil $P$ Frigerio JM, Brach J, Barre A, de Daruvar A, et al: The proteome of maritime pine wood forming tissue. Proteomics 2005, 5(14):3731-3751.

34. Valledor L, Jorrin JV, Rodriguez JL, Lenz C, Meijon M, Rodriguez R, Canal MJ: Combined proteomic and transcriptomic analysis identifies differentially expressed pathways associated to pinus radiata needle maturation. J Proteome Res 2010, 9(8):3954-3979.

35. Fan J, Chen CX, Yu QB, Brlansky RH, Li ZG, Gmitter FG: Comparative iTRAQ proteome and transcriptome analyses of sweet orange infected by "Candidatus Liberibacter asiaticus". Physiol Plantarum 2011, 143(3):235-245.

36. Gygi SP, Rochon Y, Franza BR, Aebersold R: Correlation between protein and mRNA abundance in yeast. Mol Cell Biol 1999, 19 (3):1720-1730

37. Washburn MP, Koller A, Oshiro G, Ulaszek RR, Plouffe D, Deciu C, Winzeler E, Yates JR: Protein pathway and complex clustering of correlated mRNA and protein expression analyses in Saccharomyces cerevisiae. P Natl Acad Sci USA 2003, 100(6):3107-3112.

38. Boter M, Ruiz-Rivero O, Abdeen A, Prat S: Conserved MYC transcription factors play a key role in jasmonate signaling both in tomato and Arabidopsis. Gene Dev 2004, 18(13):1577-1591.
39. Yin L, Tao Y, Zhao K, Shao JM, Li XB, Liu GZ, Liu SQ, Zhu LH: Proteomic and transcriptomic analysis of rice mature seed-derived callus differentiation. Proteomics 2007, 7(5):755-768.

40. Jamet E, Roujol D, San-Clemente H, Irshad M, Soubigou-Taconnat L, Renou JP, Pont-Lezica R: Cell wall biogenesis of Arabidopsis thaliana elongating cells: transcriptomics complements proteomics. BMC Genomics 2009, 10:505-517.

41. Zhao ZX, Zhang W, Stanley BA, Assmann SM: Functional proteomics of Arabidopsis thaliana guard cells uncovers new stomatal signaling pathways. Plant Cell 2008, 20(12):3210-3226.

42. Day RS, McDade KK, Chandran UR, Lisovich A, Conrads TP, Hood BL, Kolli VSK, Kirchner D, Litzi T, Maxwell GL: Identifier mapping performance for integrating transcriptomics and proteomics experimental results. $B M C$ Bioinforma 2011, 12:213-226.

43. Hegde PS, White IR, Debouck C: Interplay of transcriptomics and proteomics. Curr Opin Biotech 2003, 14(6):647-651.

44. Jamai A, Salome PA, Schilling SH, Weber APM, McClung CR: Arabidopsis Photorespiratory Serine Hydroxymethyltransferase Activity Requires the Mitochondrial Accumulation of Ferredoxin-Dependent Glutamate Synthase. Plant Cell 2009, 21(2):595-606.

45. Bilgin DD, Zavala JA, Zhu J, Clough SJ, Ort DR, DeLucia EH: Biotic stress globally downregulates photosynthesis genes. Plant Cell Environ 2010, 33(10):1597-1613.

46. Schwachtje J, Baldwin IT: Why does herbivore attack reconfigure primary metabolism? Plant Physiol 2008, 146(3):845-851.

47. Koyama K, Sadamatsu K, Goto-Yamamoto N: Abscisic acid stimulated ripening and gene expression in berry skins of the Cabernet Sauvignon grape. Funct Integr Genomics 2010, 10(3):367-381.

48. van de Ven WTG, LeVesque CS, Perring TM, Walling LL: Local and systemic changes in squash gene expression in response to silverleaf whitefly feeding. Plant Cell 2000, 12(8):1409-1423.

49. Konno K: Plant latex and other exudates as plant defense systems: Roles of various defense chemicals and proteins contained therein. Phytochem 2011, 72(13):1510-1530.

50. Xiong YQ, DeFraia C, Williams D, Zhang XD, Mou ZL: Characterization of Arabidopsis 6-Phosphogluconolactonase T-DNA Insertion Mutants Reveals an Essential Role for the Oxidative Section of the Plastidic Pentose Phosphate Pathway in Plant Growth and Development. Plant Cell Physiol 2009, 50(7):1277-1291.

51. Verhage A, van Wees SCM, Pieterse CMJ: Plant immunity: It's the hormones talking, but what do they say? Plant Physiol 2010, 154(2):536-540.

52. Estes AM, Hearn DJ, Bronstein JL, Pierson EA: The olive fly endosymbiont, "Candidatus erwinia dacicola", switches from an intracellular existence to an extracellular existence during host insect development. Appl Environ Microb 2009, 75(22):7097-7106.

53. Kounatidis I, Crotti E, Sapountzis P, Sacchi L, Rizzi A, Chouaia B, Bandi C, Alma A, Daffonchio D, Mavragani-Tsipidou P, et al: Acetobacter tropicalis Is a Major Symbiont of the Olive Fruit Fly (Bactrocera oleae). Appl Environ Microb 2009, 75(10):3281-3288.

54. Walling LL: The myriad plant responses to herbivores. J Plant Growth Regul 2000, 19(2):195-216.

55. Dixon RA, Achnine L, Kota P, Liu CJ, Reddy MSS, Wang LJ: The phenylpropanoid pathway and plant defence - a genomics perspective. Mol Plant Pathol 2002, 3(5):371-390

56. Truman W, Bennettt MH, Kubigsteltig I, Turnbull C, Grant M: Arabidopsis systemic immunity uses conserved defense signaling pathways and is mediated by jasmonates. P Natl Acad Sci USA 2007, 104(3):1075-1080.

57. Mizutani M, Ohta D, Sato R: Isolation of a cDNA and a genomic clone encoding cinnamate 4-hydroxylase from Arabidopsis and its expression manner in planta. Plant Physiol 1997, 113(3):755-763.

58. Benitez Y, Botella MA, Trapero A, Alsalimiya M, Caballero JL, Dorado G, Munoz-Blanco J: Molecular analysis of the interaction between Olea europaea and the biotrophic fungus Spilocaea oleagina. Mol Plant Pathol 2005, 6(4):425-438.

59. Taylor JE, Hatcher PE, Paul ND: Crosstalk between plant responses to pathogens and herbivores: a view from the outside in. J Exp Bot 2004, 55(395):159-168.

60. Xu L, Zhu LF, Tu LL, Guo XP, Long L, Sun LQ, Gao W, Zhang XL: Differential gene expression in cotton defence response to Verticillium dahliae by SSH. J Phytopathol 2011, 159(9):606-615. 
61. Terra WR, Cristofoletti PT: Midgut proteinases in three divergent species of Coleoptera. Comp Biochem Phys B 1996, 113(4):725-730.

62. Silva F, Alcazar A, Macedo LLP, Oliveira AS, Macedo FP, Abreu LRD, Santos EA, Sales MP: Digestive enzymes during development of Ceratitis capitata (Diptera: Tephritidae) and effects of SBTI on its digestive serine proteinase targets. Insect Biochem Mol Biology 2006, 36(7):561-569.

63. Huvenne $H$, Smagghe $G$ : Mechanisms of dsRNA uptake in insects and potential of RNAi for pest control: A review. J Insect Physiol 2010, 56(3):227-235.

64. Zhu-Salzman K, Luthe DS, Felton GW: Arthropod-inducible proteins: Broad spectrum defenses against multiple herbivores. Plant Physiol 2008 146(3):852-858.

65. Lawrence SD, Novak NG, Ju CJT, Cooke JEK: Potato, Solanum tuberosum, defense against colorado potato beetle, Leptinotarsa decemlineata (Say): Microarray gene expression profiling of potato by colorado potato beetle regurgitant treatment of wounded leaves. J Chem Ecol 2008, 34(8):1013-1025.

66. Corrado G, Arciello S, Fanti P, Fiandra L, Garonna A, Digilio MC, Lorito M, Giordana B, Pennacchio F, Rao R: The Chitinase A from the baculovirus AcMNPV enhances resistance to both fungi and herbivorous pests in tobacco. Transgenic Res 2008, 17(4):557-571.

67. Rao R, Fiandra L, Giordana B, de Eguileor M, Congiu T, Burlini N, Arciello S, Corrado G, Pennacchio F: AcMNPV ChiA protein disrupts the peritrophic membrane and alters midgut physiology of Bombyx mori larvae. Insect Biochem Mol Biol 2004, 34(11):1205-1213.

68. van Loon LC, Rep M, Pieterse CMJ: Significance of inducible defenserelated proteins in infected plants. Annu Rev Phytopathol 2006, 44:135-162.

69. Xie WL, Goodwin PH: A PRp27 gene of Nicotiana benthamiana contributes to resistance to Pseudomonas syringae pv. tabaci but not to Colletotrichum destructivum or Colletotrichum orbiculare. Funct Plant Biol 2009, 36(4):351-361.

70. Okushima Y, Koizumi N, Kusano T, Sano H: Secreted proteins of tobacco cultured BY2 cells: identification of a new member of pathogenesisrelated proteins. Plant Mol Biol 2000, 42(3):479-488.

71. Margaria P, Palmano S: Response of the Vitis vinifera L. cv. 'Nebbiolo' proteome to Flavescence doree phytoplasma infection. Proteomics 2011, 11(2):212-224

72. Sambrook J, Fritsh EF, Maniatis T: Molecular cloning, a laboratory manual. Secondth edition. Cold Spring Harbor, NY: Cold Spring Harbor Laboratory Press; 1989.

73. Huang XQ, Madan A: CAP3: A DNA sequence assembly program. Genome Res 1999, 9(9):868-877.

74. Altschul SF, Madden TL, Schaffer AA, Zhang JH, Zhang Z, Miller W, Lipman DJ: Gapped BLAST and PSI-BLAST: a new generation of protein database search programs. Nucleic Acids Res 1997, 25(17):3389-3402.

75. Gasteiger E, Gattiker A, Hoogland C, Ivanyi I, Appel RD, Bairoch A: ExPASy: the proteomics server for in-depth protein knowledge and analysis. Nucleic Acids Res 2003, 31(13):3784-3788.

76. Conesa A, Gotz S, Garcia-Gomez JM, Terol J, Talon M, Robles M: Blast2GO: a universal tool for annotation, visualization and analysis in functional genomics research. Bioinformatics 2005, 21(18):3674-3676.

77. Marchler-Bauer A, Anderson JB, Chitsaz F, Derbyshire MK, DeWeese-Scott C, Fong JH, Geer LY, Geer RC, Gonzales NR, Gwadz M, et al: CDD: specific functional annotation with the Conserved Domain Database. Nucleic Acids Res 2009, 37:D205-D210.

78. Emanuelsson O, Brunak S, von Heijne G, Nielsen H: Locating proteins in the cell using TargetP, SignalP and related tools. Nat Protoc 2007, 2(4):953-971.

79. Bannai H, Tamada Y, Maruyama O, Nakai K, Miyano S: Extensive feature detection of $\mathrm{N}$-terminal protein sorting signals. Bioinformatics 2002, 18(2):298-305.

80. Digilio MC, Corrado G, Sasso R, Coppola V, lodice L, Pasquariello M, Bossi S, Maffei ME, Coppola M, Pennacchio F, et al: Molecular and chemical mechanisms involved in aphid resistance in cultivated tomato. New Phytol 2010, 187(4):1089-1101.

81. Corrado G, Sasso R, Pasquariello M, lodice L, Carretta A, Cascone P, Ariati L, Digilio MC, Guerrieri E, Rao R: Systemin regulates both systemic and volatile signaling in tomato plants. J Chem Ecol 2007, 33(4):669-681.

82. Wang W, Vignani R, Scali M, Cresti M: A universal and rapid protocol for protein extraction from recalcitrant plant tissues for proteomic analysis. Electrophoresis 2006, 27(13):2782-2786.
83. Rocco M, Corrado G, Arena S, D'Ambrosio C, Tortiglione C, Sellaroli S, Marra $M$, Rao R, Scaloni A: The expression of tomato prosystemin gene in tobacco plants highly affects host proteomic repertoire. JProteomics 2008, 71(2):176-185

84. Vascotto C, Cesaratto L, D'Ambrosio C, Scaloni A, Avellini C, Paron I, Baccaranil U, Adani GL, Tribelli C, Quadrifoglio F, et al: Proteomic analysis of liver tissues subjected to early ischemia/reperfusion injury during human orthotopic liver transplantation. Proteomics 2006, 6(11):3455-3465.

85. Scippa GS, Rocco M, lalicicco M, Trupiano D, Viscosi V, Di Michele M, Arena S, Chiatante D, Scaloni A: The proteome of lentil (Lens culinaris Medik.) seeds: Discriminating between landraces. Electrophoresis 2010 31(3):497-506.

doi:10.1186/1471-2229-12-86

Cite this article as: Corrado et al: Molecular interactions between the olive and the fruit fly Bactrocera oleae. BMC Plant Biology 2012 12:86.

\section{Submit your next manuscript to BioMed Central and take full advantage of:}

- Convenient online submission

- Thorough peer review

- No space constraints or color figure charges

- Immediate publication on acceptance

- Inclusion in PubMed, CAS, Scopus and Google Scholar

- Research which is freely available for redistribution 